\title{
Small islands in the big picture: the formative period of Lapita in the Bismarck Archipelago
}

\author{
Jim Specht
}

\author{
Anthropology Unit \\ Australian Museum Sydney \\ NSW 2010, Australia \\ jspecht@bigpond.com
}

Locations with dentate-stamped Lapita pottery are widely viewed as expressions of activities associated with 'settlements,' 'hamlets' or 'villages.' Such terms run the danger of concealing spatial diversity of function and differentiation of activities, with the obvious exception of burial grounds such as Teouma in Vanuatu (Bedford et al. 2006). Often this situation is the inevitable outcome of the small scale examination of sites, as commonly such small areas are sampled that it is impossible to discuss issues of site structure and spatial differentiation. The few exceptions to this approach include the RF-2 site in the SE Solomons (Green 1976; Green and Pawley 1998; Sheppard and Green 1991), the ECA complex on Eloaua Island (Kirch 1988a, 2001a), the Makekur site in the Arawe Islands (Gosden and Webb 1994), and SAC on Watom Island (Anson et al. 2005; Green and Anson 2000). In each case sampling programs and / or areal excavations allowed significant insights into the sedimentary history and internal organisation of human use of the areas. People do not conduct their lives in one spot, but distribute their activities across the landscape and, in coastal locations, the sea (e.g., Gosden 1989). No one locality is sufficient for gardening, fishing, hunting, raw material extraction, canoe building and other industrial production, food preparation and consumption, dying, trading and ceremonial or religious activities. While some activities leave distinctive or unique archaeological 'signatures,' others do not. The result is that a group of people generates a range of archaeological 'signatures' over time and space that may reflect these different activities, and the interpretation of these activities should be argued from the evidence, rather than by assumption. This applies particularly to Lapita period use of offshore islands. I propose in this paper that some very small islands in the Bismarck Archipelago might have been used for purposes other than day-to-day living, perhaps as places for the conduct of ritual or ceremonial activities. This invites consideration of a possible analogous relationship with the construction 
of stilt buildings over inter-tidal reefs, which seems characteristic of many Lapita pottery sites in Near Oceania (Felgate 2003; Gosden and Webb 1994; Kirch 1988a; Specht 1991; Wickler 2001).

Interpretations of dentate-stamped Lapita pottery sites in non-secular, religious or ceremonial terms have come to the fore over the last decade. Terrell and Welsh (1997:568) suggested that in the Bismarck Archipelago 'Lapita pots were culture elements in the material paraphernalia ...of some kind of cult, dance complex or social ritual.' Less specifically, Kirch (1997:147) noted possible differences in the functions of dentate-stamped decorated vessels and those with no decoration at the ECA site in the Mussau Islands, and Summerhayes (2000a:62) extended this possibility in utilitarian and non-utilitarian terms to the entire Bismarck Archipelago. Kirch (2001a: 103) also proposed that the 'special objects and ceramics' associated with the stilt structure of ECA/B could indicate that the building had a 'special-function.' The striking nature of the ECA/ B finds led him to introduce the idea of 'house societies' as a potential organising principle for societies within the Lapita cultural complex (Kirch 1997:188-191), and Chiu $(2003,2005)$ explicitly used this concept in her study of New Caledonian Lapita pottery. Best (2002:98-100) speculated on the ideological basis of the Lapita design system and the rapid dispersal of Lapita potters, and invoked the possibility of 'a charismatic individual able to manipulate and enlarge an established hierarchical and religious system.' Spriggs (2002, 2003a) applied some of Best's ideas to the 'post-Lapita' period, suggesting that its beginning was not marked by the end of the dentate-stamped technique, but by the breakdown of the design system to the point where it became 'faceless' and presumably lost much of its meaning, even though dentate-stamped designs persisted (Spriggs 2002:55). Finally, Noury (2005) combined aspects of these authors' ideas, particularly 'house societies' and respect for the ancestors, in the context of funerary ritual.

This brief review of recent interpretations only scratches the surface, but illustrates that the nonsecular role of some Lapita vessels and locations is firmly established in the literature. The comments of Terrell and Welsch, Summerhayes and Kirch relate directly to the Bismarck Archipelago, which for a long time has been regarded as the 'homeland' of the Lapita cultural complex (Allen 1984; Green 1979). The rest of this paper focuses on that region, but is not concerned with debates on ultimate origins or the introduction of Austronesian languages from insular Southeast Asia (e.g., Green 2003; Kirch 1996, 1997; Spriggs 1996, 1997; Terrell 1998). I accept that some aspects of the Lapita cultural complex had their origins outside the Bismarck Archipelago, but am not concerned with how they came into the Archipelago. The paper occasionally extends to Nissan Island in the north Solomons on account of that island's position between the Archipelago and more southerly expressions of Lapita (Spriggs 1991, 2000) ${ }^{1}$.

This paper does not present new data, but reviews aspects of existing data and interpretations. It first looks at matters of dating. Once pottery production was established in the Bismarck Archipelago there was a 'pause' before dispersal into Remote Oceania. When did this 'Bismarck pause' occur and how long did it last? Next it reviews briefly various schemes used to describe the period of dentate-stamped pottery development in the Bismarck Archipelago and introduces the idea of a 'formative' period. The third part discusses the location of sites in the Archipelago and possible reasons for their selection, particularly those on offshore islands. Finally, it considers the pottery from various sites and suggests a possible interpretation of some locations on tiny islands and their possible humanly constructed equivalents in the form of structures over inter-tidal reefs.

\section{How long was the 'Bismarck pause'?}

The length of the pause in the Bismarck Archipelago is critical for understanding the developments that led to the formation of the Lapita phenomenon before its southerly dispersal into Remote Oceania. The temporal limits of this pause are set by the earliest dates for Lapita pottery in the Archipelago and for its presence to 
the south. Here I review briefly the evidence and offer a revised date of 3450-3350 cal. BP for the appearance of Lapita pottery that replaces the 3300-3200 cal. BP date that I once supported (Specht and Gosden 1997).

Kirch and Hunt (1988a:164) concluded that 'the Lapita horizon in Melanesia spans the period from ca 1600-500 BC,' and that there was no evidence for a substantial pause in the Bismarck Archipelago as required by Anson's (1986) proposal for a 'Far Western' stage. Additional evidence has led to a modified view and the pause is now variously estimated at between 200 to 400 years (e.g., Kirch 1997:58-62; Spriggs 2002:52). The initial date for the appearance of Lapita pottery in the Bismarck Archipelago, however, has remained an issue. Specht and Gosden (1997:188) questioned the 3550 cal. BP date preferred by Kirch and Hunt, and proposed 3300-3200 cal. BP in an attempt to resolve a discrepancy between the Mussau and New Britain dates, while allowing the possibility that pottery began in the Mussau group slightly before its appearance in New Britain. Green (2003: Fig. 3) and Summerhayes (2001a; 2004:Table 1) have opted for ca 3500 cal. BP. Kirch (2001b:219) now entertains an initial date possibly as late as 3350-3250 cal. BP, while noting that older results from ECA/ A and ECB 'hint at settlement one or even two centuries earlier' than this, around 3550-3450 cal. BP.

All of these estimates were based on results from plant and marine shell samples. Marine shell samples are now recognised as being extremely problematic in the Bismarck Archipelago, as they require locality-specific $\Delta \mathrm{R}$ values rather than the default value of $0 \pm 0$ years or some generalised regional value (Kirch 2001b; Petchey et al. 2004, 2005:37). Unfortunately, few locality-specific values are available for the Archipelago, and those that are available display considerable variability (Kirch 2001b; Petchey et al. 2004, 2005; Summerhayes in press). On the other hand, the number of dates on plant-derived materials is now sufficient to discuss the initial date of Lapita pottery without reference to marine shell samples. In choosing this approach I assume that the oldest levels of the sites have been dated by plant-derived samples, though this may not always be so.

Table 1 presents 26 radiocarbon dates on charcoal, carbonised nutshells or wood from 11 sites in the Bismarck Archipelago and on Nissan Island. It includes 12 dates published after the Specht and Gosden (1997) review. The results have been calibrated with the atmospheric dataset of the CALIB 5.0.1 program (Reimer et al. 2004; Stuiver and Reimer 1993 [version 5]), expressed as $2 \sigma$ ranges, with short-lived nutshell samples assigned a one-year growth span, and wood and charcoal samples a nominal ten-year growth span. The Table includes only samples excavated from stratigraphic units directly associated with plain or dentatestamped Lapita pottery, and with the upper end of their $2 \sigma$ age range exceeding 3000 years cal. BP for the highest probability distribution (HPD, $\mathrm{p}=1$ or $>0.9$ ). The Table omits results with calibrated ranges that are clearly too old and/or with standard deviations exceeding 120 years that produce very large age spans. This cut-off point is arbitrary ${ }^{2}$.

The calibrated ranges are ordered from oldest to youngest according to the upper end of their ranges. As with previous reviews the oldest dates with upper limits exceeding $3500 \mathrm{cal}$. BP (Beta-20453: 3573-3262 cal. BP; Beta-30864: 3563-2996 cal. BP) are from ECA and ECB, and have ranges exceeding the next oldest sample by over 150 years (Beta-20452: 3404-3060 cal. BP, from ECA /B). Beta-30864 has a large standard deviation that yields the widest age span (567 years) on Table 1. This span embraces the ranges of all but two of the next seven oldest dates, suggesting that we should not place too much reliance on this sample. Kirch (2001b:231) has reservations about Beta-20453 and raises the possibility of the sample including 'old wood' with in-built age. The next seven oldest dates, which have upper limits between 3300 and $3400 \mathrm{cal}$. BP, extend the geographical range of sites to the Anir group and to Nissan and Garua Islands. Three of these dates (Beta-72144, Wk-7563 and NZA-3734) are essentially the same as Beta-20452, though Kirch $(2001 \mathrm{~b}: 214,231)$ suggests that Beta-20452 could be from old wood, as its associated pottery seems to conflict with that found with Beta-30684 in another part of ECA.

The two oldest dates at ECA and ECB (Beta-20453, Beta-30864) thus contrast strongly with the main series of dates for the Bismarck Archipelago, which indicate that Lapita pottery was widespread throughout the Archipelago and on Nissan by or soon after 3400-3350 cal. BP. Leaving the two 'outlier' dates to one side for the moment, I suggest that the upper limit for Lapita pottery is likely to be about 3450-3400 cal. BP in the 
Table 1. Radiocarbon dates on plant-derived materials for Lapita pottery deposits in the Bismarck Archipelago and on Nissan Island, arranged from oldest to youngest by their highest probability distribution (HPD) ranges. See text and endnote 2 for details of sample selection and calibration. 'WP isthmus' refers to the base of Willaumez Peninsula on New Britain. Sources: Eloaua - Kirch 2001b; Garua - Torrence and Stevenson 2000; Adwe and Anir - Summerhayes 2001a; Willaumez Peninsula isthmus - Specht and Torrence, this volume; Watom - Petchey et al. 2005; Nissan - Spriggs 2003b; Makada - White and Harris 1997.

\begin{tabular}{|c|c|c|c|c|c|c|c|c|c|}
\hline $\begin{array}{c}\text { Island or } \\
\text { region }\end{array}$ & $\begin{array}{l}\text { Site } \\
\text { code }\end{array}$ & $\begin{array}{c}\text { Excavation } \\
\text { context }\end{array}$ & Material & Lab. code & CRA & $\begin{array}{c}\text { Cal. range } \\
\text { at } 2 \sigma\end{array}$ & $\begin{array}{c}\text { Cal. range } \\
\text { at HPD }\end{array}$ & $\begin{array}{l}\text { HPD } \\
\text { prob. }\end{array}$ & $\begin{array}{l}\text { HPD } \\
\text { span }\end{array}$ \\
\hline Eloaua & $\mathrm{ECB}$ & Unit 9, level 5 & charcoal & Beta-20453 & $3200 \pm 70$ & $3573-3261$ & $3573-3261$ & 1,000 & 312 \\
\hline Eloaua & ECA & W250N170 level 3 & wood & Beta-30684 & $3100 \pm 110$ & $3563-2996$ & $3563-2996$ & 1,000 & 567 \\
\hline Eloaua & $\mathrm{ECA} / \mathrm{B}$ & W198N145, C3, post B30 & wood & Beta-20452 & $3050 \pm 70$ & $3438-3007$ & $3404-3060$ & 0,987 & 344 \\
\hline Garua & FYS & II, layer 5 spit 3 & nutshell & Beta-72144 & $3060 \pm 60$ & $3390-3078$ & $3390-3078$ & 1,000 & 312 \\
\hline Anir & ERA & TP1, spit 9 & charcoal & Wk-7563 & $3075 \pm 45$ & $3386-3162$ & $3386-3201$ & 0,964 & 185 \\
\hline Garua & FYS & II, layer 5 spit 4 & nutshell & NZA-3734 & $3030 \pm 69$ & $3381-3005$ & $3381-3058$ & 0,965 & 323 \\
\hline Anir & ERA & TP1, spit 6 & charcoal & Wk-7561 & $3035 \pm 45$ & $3361-3080$ & $3361-3139$ & 0,951 & 222 \\
\hline Nissan & $\mathrm{DGD} / 2$ & Layer $4(110-120 \mathrm{~cm})$ & charcoal & ANU-6809 & $2990 \pm 60$ & $3347-2997$ & $3347-2997$ & 1,000 & 350 \\
\hline Eloaua & $\mathrm{ECA} / \mathrm{B}$ & W200N150, post B1 & wood & ANU-5790 & $2950 \pm 80$ & $3400-2887$ & $3340-2921$ & 0,983 & 419 \\
\hline Eloaua & $\mathrm{ECA} / \mathrm{A}$ & W200N120, III level 9 & coconut shell & Beta-20451 & $2950 \pm 70$ & $3335-2926$ & $3335-2926$ & 1,000 & 409 \\
\hline Eloaua & $\mathrm{ECA} / \mathrm{B}$ & W199N151, post B2 & wood & ANU-5791 & $2930 \pm 80$ & $3329-2872$ & $3271-2872$ & 0,955 & 399 \\
\hline Eloaua & $\mathrm{ECA}$ & W250N140, level 6, post & wood & Beta-30682 & $2970 \pm 50$ & $3327-2988$ & $3270-2988$ & 0,946 & 282 \\
\hline WP isthmus & FADC & LVI, layer 9 spit 3 & nutshell & Wk-12845 & $2963 \pm 47$ & $3320-2976$ & $3265-2976$ & 0,966 & 289 \\
\hline Eloaua & $\mathrm{ECA} / \mathrm{B}$ & W200N150, levels 12-13 & charcoal & ANU-5079 & $2840 \pm 115$ & $3318-2751$ & $3264-2751$ & 0,992 & 513 \\
\hline Adwe & $\mathrm{FOH}$ & E2 spit 9 & charcoal & ANU-11186 & $2800 \pm 110$ & $3241-2740$ & $3241-2740$ & 1,000 & 501 \\
\hline Garua & FYS & II, layer 5 spit 1 & nutshell & NZA-3733 & $2883 \pm 64$ & $3216-2851$ & $3216-2851$ & 1,000 & 365 \\
\hline Adwe & $\mathrm{FOH}$ & TP21B, spit 13 & charcoal & Beta-54165 & $2850 \pm 80$ & $3209-2784$ & $3172-2784$ & 0,965 & 388 \\
\hline WP isthmus & FAAH & XVII, layer 9 spit 1 & nutshell & Wk-10463 & $2880 \pm 59$ & $3209-2859$ & $3170-2859$ & 0,960 & 311 \\
\hline Eloaua & ECA & W250N120, level 9, post & wood & Beta-30681 & $2860 \pm 60$ & $3206-2808$ & $3166-2844$ & 0,976 & 322 \\
\hline Watom & SAC & G13, spit 2 & coconut shell & Wk-7370 & $2860 \pm 60$ & $3207-2844$ & $3165-2844$ & 0,975 & 321 \\
\hline Eloaua & $\mathrm{ECA} / \mathrm{C}$ & W250N188, post C3 & wood & Beta-30686 & $2850 \pm 70$ & $3204-2791$ & $3164-2791$ & 0,983 & 373 \\
\hline Adwe & $\mathrm{FOH}$ & D3, spit 9 & charcoal & ANU-11187 & $2730 \pm 100$ & $3159-2542$ & $3159-2700$ & 0,977 & 459 \\
\hline Nissan & $\mathrm{DGD} / 2$ & Layer $4(100-110 \mathrm{~cm})$ & charcoal & ANU-8301 & $2820 \pm 70$ & $3144-2771$ & $3082-2771$ & 0,948 & 311 \\
\hline WP isthmus & FAAH & XVII, layer 9 spit 3 & nutshell & Wk-19190 & $2847 \pm 34$ & $3067-2868$ & $3067-2868$ & 1,000 & 199 \\
\hline Garua & FSZ & $13 / 92$, layer $1 / 2$ & nutshell & NZA-6099 & $2781 \pm 68$ & $3063-2758$ & $3063-2758$ & 1,000 & 305 \\
\hline Makada & SEP & TP2, layer 1 & charcoal & SUA-3062 & $2730 \pm 80$ & $3062-2729$ & $3039-2729$ & 0,991 & 310 \\
\hline
\end{tabular}

Mussau group, and 3400-3350 cal. BP or slightly earlier in New Britain and New Ireland. For New Britain, this range falls squarely within the revised range of 3480-3200 cal. BP for the W-K2 volcanic event that devastated the central part of the island, and this suggests quite rapid re-colonisation of the area after the eruption (Petrie and Torrence in prep; Specht and Torrence, this volume). The difference of 50-100 years between the Mussau sites and those of New Britain-New Ireland may be more apparent than real, given the nature of radiocarbon dates and issues surrounding their calibration (Kirch 2001b:220). A slightly earlier date for Mussau, however, would be consistent with Kirch's claim for a red-slipped plain ware phase preceding the main dentate-stamped phase at ECA, an issue to which I return later. For this paper I use 3450-3350 cal. BP for the appearance of Lapita pottery in the Bismarck Archipelago.

The dispersal out of the Bismarck Archipelago is indicated by the oldest dates in more southerly sites. Pottery imported from New Britain and the New Ireland region (Dickinson 2006:Table 25D9, 113, 139) reached Nissan soon after its appearance in the Bismarck Archipelago (ANU-6809 on Table 1). This could represent the first stages of the dispersal, though we do not know whether the transfer of pottery to Nissan also involved the relocation of people. Further south, the next oldest dates are in the Reef Islands of the SE Solomons, where four charcoal dates for the RF-2 site are usually cited as a pooled mean of 3137-2826 cal. BP (Green 1991a:201, Table 3). Three of these dates have calibrated ranges older than the pooled mean (I-5747: 3357-2877 cal. BP; ANU-6476: 3275-2750 cal. BP; ANU-6477: 3210-2678 cal. BP). Three charcoal samples at the 
Atanoasao site on Malo in Vanuatu have similar ranges: 3237-2754 cal. BP (Beta-110143), 3209-2885 cal. BP (Beta-110144) and 3141-2785 cal. BP (Beta-110146) (Galipaud 2000:49; Pineda and Galipaud 1998). In Fiji, the Bourewa site has two charcoal dates of 3205-2889 cal. BP (Wk-14237) and 3141-2868 cal. BP (Wk-14236) (Nunn et al. 2004). Considered together, these results suggest that the southerly dispersal of Lapita pottery began around 3250-3200 cal. BP, within 100-200 years of its appearance in the Bismarck Archipelago. The pause was thus probably slightly shorter than is currently accepted.

\section{The 'formative' period}

The initial scheme for dividing the Lapita phenomenon in time and space established Western and Eastern Lapita regions (Green 1979). Although these terms were geographical, the Eastern group of sites was acknowledged as younger than the Western ones. Anson (1986) introduced a 'Far Western Bismarck' stage preceding Western Lapita in the Bismarck Archipelago, adding a further temporal dimension to the geographical term. Spriggs (1995:116; 1997:70) made this more explicit by re-naming Anson's stage 'Early Western.' An alternative approach is based on temporal units (Early, Middle and Late Lapita), on the grounds that changes in Lapita pottery across its distribution were more correlated with time than with distance (Summerhayes 2000b, 2001b, 2001c). Green (2003:Fig. 3) later combined aspects of both time and space in his scheme of local Lapita traditions that had their own geographical and temporal dimensions.

Green's local traditions incorporated Kirch's (1996:65, 2001a:85, 2001b:219) suggestion of a redslipped plain ware phase at ECA preceding the florescence of dentate-stamped decoration on Eloaua Island in the Mussau area, consistent with the proposed derivation of Lapita pottery from comparable wares in island Southeast Asia (Bellwood 1992; Kirch 1996:65, 1997:141). The dating of the putative ECA phase, however, relies heavily on the choice of $\Delta \mathrm{R}$ value for calibrating marine shell dates and, as Kirch (2001b: 213-214, 219) acknowledged, the choice can affect results by several hundred years. The phase has not been identified in other parts of the Bismarck Archipelago, though red-slipped plain sherds and dentate-stamped sherds co-occur in the oldest levels of FYS and FEA in the Talasea area and at FAAH on the Willaumez Peninsula isthmus (Specht and Summerhayes in press; Specht and Torrence in press, this volume). While this absence could reflect the slightly younger dates for other Bismarck sites, I suggest below another interpretation.

Given the uncertainty about the earliest stages of Lapita pottery development in the Bismarck Archipelago, I suggest that it would be useful to adopt a more general term for the period under discussion, and refer to it as the 'formative period.' For adherents of the Lapita-as-new-people model, the formative period encompasses the time required for the 'integration' and 'innovation' aspects of the Triple-I model (Green 1991b, $2000,2003)$. The period witnessed developments in the pottery and arguably other elements of material and social culture that laid the foundation for the later dispersal into Remote Oceania. It embraced the entire Bismarck region, as pottery comparable to that of ECA / B occurs in the Arawe Islands (Summerhayes 2000a, 2000b), the Duke of York Islands (White in press), the Talasea area (Specht and Summerhayes in press; Specht and Torrence in press), the Anir group (Summerhayes 2001a, 2001b), and on Nissan (Spriggs 1991:239, 1997:126) ${ }^{3}$.

\section{The location of Lapita sites}

The most detailed studies of Lapita site locations remain those of Frimigacci (1980), who dealt in general terms with major landscape and seascape features, and Lepofsky (1988), who employed a site catchment analysis approach. Here I extend Lepofsky's (1988:Table 3.3) use of island size to look more closely at the islands on which Lapita sites occur. Lepofsky (1988:42) found that 'Lapita sites are more densely packed 
on small islands than on large ones,' but noted that 'it is difficult to evaluate what these results actually tell us about Lapita settlement patterns.' A particular problem facing her was the 'comparability of the surveys conducted on large islands with those on smaller ones.' Since her innovative paper, much new data has become available.

The regular occurrence of dentate-stamped Lapita pottery sites on small offshore islands or in coastal locations on large islands has long been acknowledged (Frimigacci 1980; Green 1979; Groube 1971; Spriggs 1984), though recent studies in New Britain and Fiji have revealed dentate-stamped pottery at inland and upland situations (Anderson et al. 2000, 2001:Table 1; Kumar 2002; Kumar and Nunn 2003; Specht and Torrence, this volume; Torrence and Stevenson 2000). The distribution of the earliest sites in the Bismarck Archipelago nevertheless remains heavily weighted towards coastal and offshore island situations, even after allowing for bias in site discovery strategies and post-Lapita geomorphic changes, especially on larger islands (Spriggs 1984, 1997:118; Torrence and Stevenson 2000).

Marked differences in the size of dentate-stamped pottery sites have also been acknowledged for a long time. Some of the smallest sites occur in caves and rock shelters, which naturally impose physical constraints on site size. Open sites, on the other hand, range from small $\left(500-5000 \mathrm{~m}^{2}\right)$ to very large $\left(>80,000 \mathrm{~m}^{2}\right)$ (Anderson et al. 2001:Table 1; Kirch 1997:167; Sheppard and Green 1991:100, Fig.18). These have been interpreted as settlements of different scales such as 'hamlets' or 'villages' (Green 1979:31; Kirch 1997:166-167; Kirch and Hunt 1988a:Table 2.1). Site size, however, reflects not only the number of people using a location, but also the activities undertaken and the length of use of a particular space, during which the locales of activities might have been periodically relocated. Examples of this are expressed at ECA and ECB on Eloaua and FOH on Adwe in the Bismarck Archipelago, where relocation of activities over time was possible as lowering of sea level and prograding shorelines created new land (Gosden and Webb 1994:Fig.8; Kirch 1988a, 2001a:Figs. 4.45, 4.47). This progressive relocation of activities resulted in a horizontal stratigraphy covering several centuries. In such situations it is inappropriate to assume that the total area now covered by cultural refuse of the Lapita period was occupied or used at any one time.

The kinds of landscape changes identified on Eloaua and Adwe increased the land area of the islands, though the islands remained small. But how big is a 'small' island? Many authors use 'small' without reference to a scale by which the reader can assess what they mean. Boduna Island ( $\sim$ ha.), for example, is small relative to Garua Island $\left(\sim 9 \mathrm{~km}^{2}\right)$, but Garua in turn is small relative to New Britain $\left(\sim 41,000 \mathrm{~km}^{2}\right)$ (Table 2). The same applies to Adwe, Pililo and Kumbun Islands relative to New Britain, Eloaua and Emananus relative to Mussau, Makada relative to Duke of York Island and both relative to New Britain and New Ireland, and Babase relative to Ambitle. Unspecific terms such as 'large' and 'small' obscures these differences.

The capacity to locate and occupy successfully remote small landmasses has been one of the defining features of Pacific peoples throughout their history (Kirch 2000), though the degree of isolation and size of an island can set severe constraints on the ability of a population to survive and expand. This is particularly true of atolls that have limited land area and even more limited natural resources (Pisarik 1975; Weisler 2001a, 2001b). This is not the case in the Bismarck Archipelago, where Lapita sites on islands are always close to a larger landmass and inter-island visibility is the norm. Occupants of offshore islands were not dependent solely on the resources immediately available to them, but could exploit those of larger nearby islands either directly or through exchange.

On Table 2 the islands in the Bismarck Archipelago with dentate-stamped pottery are arranged in four arbitrary groups that represent current size and not that at the time of Lapita use: those $1 \mathrm{~km}^{2}$ or less in area, those between $1 \mathrm{~km}^{2}$ and $10 \mathrm{~km}^{2}$, those between $10 \mathrm{~km}^{2}$ and $50 \mathrm{~km}^{2}$, and those above $50 \mathrm{~km}^{2}$. New Ireland and New Britain are included for contrasts of scale, and the numbers of sites are approximate only, as it is not always clear whether adjacent locations with dentate-stamped sherds should be treated as one or more sites. The Table suggests a slight preference for islands less than $10 \mathrm{~km}^{2}$ in area (49 sites out of 91), though sample 
Table 2. Sizes of islands in the Bismarck Archipelago where pottery of the Lapita ceramic series has been recovered. The data are drawn from literature statements and topographic maps, and are approximate only. Numbers in brackets with each entry indicate the number of locations where pottery has been recovered.

\begin{tabular}{|c|c|c|c|c|}
\hline & Less than $1 \mathrm{~km}^{2}$ & 1 to $10 \mathrm{~km}^{2}$ & 10 to $50 \mathrm{~km}^{2}$ & $>50 \mathrm{~km}^{2}$ \\
\hline Siassi Is. & & Tuam 2 km² (1) & & \\
\hline New Britain & & & & $41,000 \mathrm{~km}^{2}(\sim 20)$ \\
\hline \multirow[t]{4}{*}{ Arawe Is. } & Adwe 8 ha. (1) & Agussak $1.25 \mathrm{~km}^{2}$ (1) & & \\
\hline & & Pililo 2.5 km² (1-2) & & \\
\hline & & Maklo 3 km² (1) & & \\
\hline & & Kumbun 5 km² (2) & & \\
\hline Kandrian & & 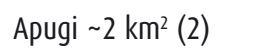 & & \\
\hline \multirow[t]{5}{*}{ Kove Islands } & Kautaga <1km² (1) & & & \\
\hline & 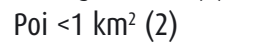 & & & \\
\hline & Talagone < km² $^{2}(1)$ & & & \\
\hline & Kalapiai < 1 km² (2) & & & \\
\hline & Kou $<1 \mathrm{~km}^{2}(1)$ & & & \\
\hline \multirow[t]{7}{*}{ Willaumez Pen. } & Boduna 1 ha. (1) & Garua 9 km² ( 7) & & \\
\hline & Depa 1 ha. (1) & & & \\
\hline & Valahia 1 ha. (1) & & & \\
\hline & Lagenda 1.5 ha. (1) & & & \\
\hline & Langu 2.5 ha. (1) & & & \\
\hline & Numundo 5 ha. (1) & & & \\
\hline & Garala 6 ha. (1) & & & \\
\hline Watom & & & Watom 14 km²(3+?) & \\
\hline \multirow[t]{4}{*}{ Duke of York Is. } & Utuan 0.5 km² (1) & 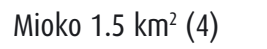 & Duke of York $50 \mathrm{~km}^{2}(8)$ & \\
\hline & Kabakon <1 km²(1) & Кегаwara 1.5 km² (2) & & \\
\hline & & Makada 3 km²(3) & & \\
\hline & & Ulu $5 \mathrm{~km}^{2}(2)$ & & \\
\hline New Ireland & & & & $9,600 \mathrm{~km}^{2}(\sim 3)$ \\
\hline \multirow[t]{2}{*}{ Mussau Is. } & Boliu -1 km² (1) & Emananus 4 km² (1) & & Mussau $350 \mathrm{~km}^{2}(1)$ \\
\hline & & Eloaua $5-7.5 \mathrm{~km}^{2}(2)$ & & \\
\hline Tanga Is. & & Lif $2 \mathrm{~km}^{2}(1)$ & & \\
\hline Anir Is. & & & Babase $30 \mathrm{~km}^{2}(2)$ & Ambitle $107 \mathrm{~km}^{2}$ (3) \\
\hline Manus Is. & Mouk 20 ha. (1) & & Baluan 25 km²(1) & Manus $2,500 \mathrm{~km}^{2}(1)$ \\
\hline Totals & $\sim 18$ & $\sim 31$ & $\sim 14$ & $\sim 28$ \\
\hline
\end{tabular}

bias is almost certainly a factor (Lepofsky 1988:42; Spriggs 1984). The Table also suggests that if dentatestamped pottery occurs on an offshore island, it is also likely to occur on a nearby larger one. The Talasea area of New Britain is a good example of this. The area has been intensively surveyed over 30 years, and has records of 18 locations with dentate-stamped pottery and 13 others with pottery but not dentate-stamped sherds (Specht and Torrence in press:Tables 1,2). Five of the seven islands in Garua Harbour have dentatestamped pottery (Boduna, Lagenda, Langu, Garala and Garua). Of these, only Garua $\left(9 \mathrm{~km}^{2}\right)$ is larger than 6 ha. The nearby mainland of Willaumez Peninsula has seven dentate-stamped pottery locations (under New Britain on Table 2), which include at least one early site (FCR/FCS; Specht 1974, in press) that Anson (1986) placed in his 'Far Western' group. The location of dentate-stamped sites, then, is not necessarily a function of time. From the earliest presence of dentate-stamped Lapita pottery in this area, people did not confine their activities to offshore islands but were using, if not occupying, the adjacent mainland.

This raises the question why people making and using Lapita dentate-stamped pottery chose to use offshore islands, especially those less than $1 \mathrm{~km}^{2}$ in area. Several possible answers can be considered. The first is suggested by the reconstructed coastal histories in the Arawe and Mussau Islands (Gosden and Webb 1994:Fig. 8; 
Kirch 1988a, 2001a:Fig. 4.45). In many areas prior to and during the early stages of Lapita pottery sea level was 1-1.5 m higher than at present and there were no beaches above high tide level suitable for occupation (Kirch 1997:163-165; Spriggs 1997:119-120). Settlement at sea level, therefore, was only possible by the construction of stilt settlements over the reef flat, as still occurs in parts of Near Oceania. The availability of a small island of only a few hectares in area, yet close to a larger and more resource-rich island, could have been an attractive alternative.

A second answer assumes that the makers of Lapita pottery were immigrants to the Bismarck Archipelago and suggests that existing populations prevented or discouraged Lapita settlement on larger landmasses (e.g., Bellwood 1978:55; Kirch 1997:166; Irwin [1981:483] expresses a contrary view). Offshore islands not claimed or used by the existing populations were available for the immigrants as living space, and provided a degree of security from potential aggression by those on the mainland who might have objected to their presence. Spriggs (1997:88) describes this as 'a defensive posture.' While this view has some appeal, it fails as a blanket answer because there is clear evidence of pre-Lapita use of Pililo and Kumbun Islands in the Arawe group (Gosden and Webb 1994; Gosden et al. 1994; cf. Specht and Gosden 1997:189), and on Nissan (Spriggs 1991). In the Mussau group, Kirch (2001a:60) specifically sought evidence for a pre-Lapita presence but was unsuccessful. While the lack of rail bones in excavated avifaunal assemblages could indicate pre-Lapita activity in the area (Steadman and Kirch 1998), other explanations are possible (Steadman 2006:128). The absence of evidence for pre-Lapita use of other offshore islands is arguably a reflection of the lack of targeted investigation. Furthermore, the 'defensive posture' line of reasoning does not apply to the Willaumez Peninsula and its adjacent islands, as this region was devastated around 3480-3200 cal. BP by deep tephra deposits from the W-K2 eruption that would have caused depopulation of the area. There is no evidence for re-settlement of the Peninsula and the adjacent islands before the appearance of people with Lapita pottery (Specht and Torrence this volume). This could explain why the FCR/FCS site was established on the mainland: in human terms, it was 'empty' space. It does not explain, however, why some people found it necessary or desirable to place themselves on the tiny islands of Garua Harbour, unless environmental conditions on the mainland made the coastline an unsuitable or unhealthy living environment. Emplacement of the W-K2 tephra and its subsequent erosion caused landscape changes in the isthmus area by infilling a shallow embayment and creating coastal swamps (Boyd et al. 2005). Comparable landscape changes could have occurred locally in parts of the Talasea area.

This takes us to the final reason for Lapita use of offshore islands: the avoidance of disease or discomfort caused by mosquitoes (and sandflies), as people on islands would 'catch more of the cooling breezes' that discourage mosquitoes, particularly Anopheline mosquitoes that are malaria vectors and which have limited ability to disperse across water (Kirch 1997:110-113; Spriggs 1997:120) ${ }^{4}$. The use of islands in Garua Harbour could have begun as a result of people at mainland locations seeking to avoid mosquito and malaria problems caused by conversion of the coastal zone into swamps after the W-K2 eruption. Occupation of offshore islands and construction of 'artificial islands' has long been seen as a strategy for avoidance of malariacarrying mosquitoes and sandflies, as well of enemies (Groves 1934:47; Ivens 1930:54; Parsonson 1965, 1968), though Chowning (1968) warns against over-emphasising the impact of malaria on human populations in Near Oceania. My personal experience is that mosquitoes and malaria can be as troublesome on offshore islands as at coastal mainland locations, particularly as many present-day villages on offshore islands in the New Britain region are on the leeward side facing the mainland, and do not necessarily catch night breezes. It is precisely in these sheltered, leeward sides of islands that Lapita pottery sites occur in the Arawes, around Kandrian and in Garua Harbour. Indeed, the distribution of pottery sites in the Talasea area generally suggests that shelter from bad weather was probably a major consideration in site selection (Specht and Torrence in press). This is reinforced by the fact that people today do not use tiny islands in Garua Harbour for permanent settlements, though some have useful functions for occasional small gardens or short-term fishing camps. Perhaps tiny offshore islands with Lapita pottery sites also had non-residential functions. I explore this possibility in the next section. 


\section{The use of offshore islands in the formative period}

Kirch's (1988a, 2001a:136, Fig. 4.47) reconstruction of the geomorphological history of the Mussau Lapita sites suggests that ECB was a stilt village in the inter-tidal zone of a small islet across a reef flat from a similar village at ECA on the main part of Eloaua ${ }^{5}$. During or after the Lapita period the islet and Eloaua were united by a slight fall in sea level and silting of the channel between them. Kirch (2001b:214) places the earliest level of ECB at about the same age as Zone C1 (sic) at ECA/B, somewhat later than the ECA/A palaeobeach. This is based on the nature of the pottery from these areas, rather than radiocarbon dates, and allows time for the proposed red-slipped plain ware phase. While there are some difficulties with Beta-20453 from ECB and Beta30684 from W250N170 at ECA, as discussed above, their ranges overlap that of Beta-20451 at ECA / A (Table 1), and this perhaps indicates that the three areas were used more or less at the same time. This, however, would seem to conflict with the nature of their pottery.

ECA/A is dominated by red-slipped plain ware, with only two dentate-stamped sherds, and W250N170 has only 'small quantities of plain ware ceramics' (Kirch 2001a:85, 2001b:229). The more extensive excavations at ECA / B yielded over 2400 decorated sherds, and ECB is described as having 'significant quantities of fine dentate-stamped pottery' (Kirch 2001a: Tables 4.1 and $4.3,85 ; 2001 \mathrm{~b}: 214)^{6}{ }^{6}$. While the difference in pottery could be a function of time or sample bias, Best (2002:97) suggests that it could reflect contemporary but different activities. The assemblage of ECA/A comprises mostly plain large jars with restricted orifices and everted rims, whereas that associated with the stilt structure of Zone $\mathrm{C}$ at ECA/B displays a diverse range of forms and decoration, including the now-famous cylinder stand (Kirch 2001a:85, 102-103). Zone C also produced a range of shell ornaments and an anthropomorphic figure carved from bone (Kirch 1988b, 2001a:103). This richness of finds led Kirch to suggest that this stilt structure might have been a 'special-function structure' (Kirch 2001a:103), and he further observed that

we must not ignore the fact that the Zone $\mathrm{C}$ deposits also contain heavy concentrations of shell and bone midden, oven stones, and food preparation equipment (scrapers and peeling knives). Thus food preparation (and consumption) was also a major activity at this structure.

This 'major activity' need not have been part of the daily round of survival, as food preparation and consumption have long been, and continue to be, essential elements of ceremonial and religious events in many cultural contexts within the Pacific Islands and beyond. We have, then, the possibility that the restricted range of forms among the ECA / A pottery is the result of domestic activities, whereas the remarkable ECA/B finds represent spatially differentiated 'major' activities of some religious or other ceremonial nature (cf. Kirch 1997:172-175). This could also apply to the pottery of ECB and perhaps EHB, where the pottery is a 'fine-dentate stamped assemblage with a high percentage of pedestalled bowls' (Kirch 2001b:219).

Separation of activities could also be reflected in the Talasea area of New Britain. Pottery from the lagoon floor and inter-tidal zone of FEA at Boduna Island differs in terms of vessel forms, aspects of decoration and sherd thickness from that excavated in 1989 (Specht and Summerhayes in press; White et al. 2002). Whereas the excavated assemblage has much in common with surface collections from the FCR/FCS site on the mainland (Specht in press), the FEA surface sherds are thick and come from large vessels of complex forms, including a cylinder stand and bowl-on-stand (Kirch's 'pedestalled bowl') (Specht and Summerhayes in press) ${ }^{7}$. With one exception, complex forms have been recorded in the Talasea area only on Boduna, Garala and Langu, each 6 hectares or less in area. The exception is a complex rim sherd from the mainland beach location of FDK (Specht and Torrence in press) ${ }^{8}$. The pottery sample from the early FYS site on Garua Island is too small for meaningful comparisons, but its few distinctive features seem consistent with FCR/FCS and the FEA excavated material. Further south in the isthmus area of Willaumez Peninsula, the only sherd from a complex form (probably a cylinder stand) came from Numundo Island (about 5-10 ha). There are none in the 
1300-plus sherds excavated at the adjacent hilltop site of FAAH. A similar spatial separation might apply in the Duke of York Islands between New Britain and New Ireland. In his review of Lapita pottery sites in this island group, White (in press) observes that

Among the sites there are two pairs, obvious in terms of their location on opposite sides of narrow sea channels. In each case, one site seems satellite to the other - SEF to SEE and SFF to SDQ - in the sense of having fewer sherds distributed over a smaller area.

This 'satellite' relationship recalls the positions of ECA and ECB prior to the silting of the channel between them, and could be repeated at ERA and ERG in the Anir Islands (Summerhayes 2001c:Fig. 3). It also recalls the distinction between the excavated and surface collections of FEA. Is it possible that during the formative period there were two kinds of contemporary Lapita pottery locations with different roles that are reflected in their associated pottery, one with a ritual or ceremonial function, the other a more mundane, domestic role (cf. Kirch 1997:172)?

I turn now to evidence for the function of the pottery. Residue analyses of plain sherds from ERA in the Anir group and Uripiv Island in Vanuatu suggest that some vessels were used in association with cooking or consumption of aroids, possibly taro (Crowther 2005; Horrocks and Bedford 2005; Bedford, personal communication). In both cases the sherds could represent the use of undecorated vessels for domestic food preparation and consumption. Bearing in mind Kirch's (2001a:103) observations on food preparation and consumption at ECA/B, perhaps highly decorated vessels were used in relation to food in non-domestic contexts, though not necessarily for cooking or storage (Kirch 1997:140; cf. Chiu 2003:242 and Summerhayes 2001c). Here the cylinder stands, pedestal stands and flat-based bowls are relevant. These occur widely, though in small numbers, in the Bismarck Archipelago and the nearer archipelagos of Remote Oceania: ECA in the Mussau group (Kirch 1997:Plate 1.1, Fig. 5.5; 2001a: Fig. 4.26); FEA on Boduna Island and Numundo Island of New Britain (Specht and Summerhayes in press; Specht and Torrence this volume); possibly SAC on Watom Island (Best 2002:82); EAQ in the Anir group (Best 2002:82); RF-2 in the Reef Islands (Best 2002:82, Fig. 25); and among the burials at Teouma in Vanuatu (Bedford et al. 2006:819). There is a possibly related form in the Arawe Islands (Summerhayes 2000b:Fig. 6.2), though Bedford et al. (2006:821) appear to discount this example. Cylinder stands seem absent from New Caledonia, though 'descendants' may occur there (Best 2002:82, citing C. Sand personal communication). More recently, Bedford et al. (2006:821) have confirmed their presence.

Kirch (1997:139-140, 294 footnote 16) interprets cylinder stands as possible supports for open bowls. This seems feasible, as circular grooves on the bases of some flat-based open bowls at Teouma (Bedford et al. 2006:819) and WKO013A in New Caledonia (Chiu 2003:174) are about the same diameter as the cylinder stand tops. In the Arawe Islands a flat base sherd has a circular ridge that could have served the same function as a groove (Summerhayes 2000b:Fig. 5.33). Chiu (2003:242) suggests that dishes or bowls attached to pedestal stands might have been used for the display or serving of food. Bowls supported on cylinder stands could have served a similar purpose.

An alterative interpretation of cylinder stands is possible. The form recalls that of recent hourglassshaped hand drums of wood found throughout the New Guinea-Bismarck Archipelago region (Kunst 1967: Endmap; McClean 1994:Figs 2a, 2b). These drums often have relief ribs around the narrow central part reminiscent of the relief bands on the ECA/B cylinder stand (Fischer 1983:Plates IX to XIII). The heads of these drums are plain and take a reptile or possum skin membrane (McClean 1994:4). The cylinder stands in the Mussau Islands also have plain tops (Kirch 1997:294 footnote 16) that seem well suited for the attachment of a membrane. In his landmark paper on face designs Spriggs (1990:119) suggested they could represent 'deities, chiefs, clan ancestors, and so on.' Kirch (1997:143-144) extended this to the pots themselves, which 'may conceivably have been regarded as representations of human beings, particularly ancestors' and related this to Lapita communities as 'house societies' (also Chiu 2005). Were cylinder stands some kind of soundproducing instrument, through which the ancestors or deities 'spoke' ${ }^{9}$ ? Such a function could be consistent 
with the recovery of cylinder stand fragments in association with the 'special-function structure' at ECA/B and in the Teouma burial ground.

This speculative suggestion is not necessarily extreme, as the Austronesian-speaking Adzera people of the upper Markham Valley of Papua New Guinea make pottery hand drums (Holzknecht 1957; May and Tuckson 1982:Fig. 6.18) ${ }^{10}$. Food-related and sound-producing uses, moreover, were clearly not the sole functions of decorated Lapita pots. At the Teouma site in Vanuatu some large, elaborately decorated vessels were used as ossuaries for secondary burials (Bedford et al. 2006). Were these vessels made explicitly for this use, or did they once have other functions but were re-purposed into funerary contexts ${ }^{11}$ ?

\section{Discussion}

There is wide acceptance of a period of development in Lapita pottery and presumably other elements of material and social culture in the Bismarck Archipelago. This I term the formative period of the Lapita cultural complex. On the basis of dates from plant-derived samples the period began about 3450-3350 cal. BP, and probably lasted no more than 100-200 years. Two dates for ECA and ECB in the Mussau group are still slightly older than those of southern New Ireland and New Britain, though whether the gap of 50-100 years between is real or a function of dating materials or techniques remains to be tested. Certainly by 3400-3350 cal. BP Lapita pottery sites were established throughout the Archipelago, and obsidian and finished pots or clays and tempers were being moved both locally and over considerable distances. The dispersal phase through southern Near Oceania into Remote Oceania began around 3250-3200 cal. BP.

Dentate-stamped Lapita sites occur on islands of all sizes in the Archipelago. Where they are on offshore islands, other Lapita pottery sites are almost always present on the adjacent 'mainland.' As early sites are in leeward locations, away from open sea or the prevailing bad weather direction, selection of their position may have had more to do with shelter than with avoidance of malaria or hostile neighbours. Of course, several factors could have come into play in the decision-making process, and not all of these were necessarily relevant to every context. Pililo, Kumbun and Nissan Islands were occupied or used long before the appearance of Lapita pottery and raise an intriguing question: if we accept the orthodox view that the introduction of pottery was the result of immigrants settling in the region, did these immigrants choose to live alongside pre-existing peoples on these islands in some kind of symbiotic relationship? This was not the case on the Willaumez Peninsula and its adjacent islands, where Lapita-using people were the first to re-colonise the area after the W-K2 eruption. In both situations, if we reject the orthodox view of immigrants, other scenarios come into play that have yet to be explored, but lie beyond the scope of this paper.

The suitability of offshore islands for the production of pottery is rarely addressed in considerations of Lapita pottery in the Bismarck Archipelago. In his prospectus for the Lapita Homeland project Allen (1984:188) observed that it is improbable that pottery was made on islands formed by elevated coral reef platforms, as they lack suitable clays. It is unlikely that the development of Lapita pottery took place solely on such islands in the Bismarck Archipelago, but must have also involved people living on geologically more complex islands. Allen's position can be questioned, as in recent times in Papua New Guinea potters on islands that lack suitable raw materials imported them from neighbouring islands or the New Guinea mainland (e.g., Bilbil, Yabob and Hus: May and Tuckson 1982:166, 330). The potters of the Amphlett Islands of SE Papua undertake a day's voyage to Fergusson Island to obtain clay (Lauer 1973:45), and on one such voyage $400 \mathrm{~kg}$ of clay was obtained (Lauer 1970:389). Furthermore, even when suitable clays do occur on offshore islands, potters sometimes seek better quality raw materials from elsewhere (e.g., Tumleo and M'buke: May and Tuckson 1982:310, 337). Similar situations probably existed in the time of Lapita pottery in the Bismarck Archipelago. 
Compositional studies of Lapita pottery in the New Britain region have demonstrated widespread local movement of finished pots or raw materials between the mainland and adjacent offshore islands in the Arawes (Summerhayes 2000b:225-229), Duke of Yorks (Thomson and White 2000), on Boduna (Specht and Summerhayes in press), and on Watom (Dickinson 2000). There is also evidence for transport of pots or raw materials over longer distances throughout the Archipelago during the formative period. Summerhayes (2000b: Fig. 11.36) identified movement between the Arawes and Garua Harbour and vice-versa. All of the Lapita pottery on Nissan was imported from Buka and the New Britain-New Ireland region (Spriggs 1991:239, 1997:126; Dickinson 2006:Table 25D9, Appendix Table A1). At the Lapita sites in the Mussau Islands, Hunt (1989:213, 215; cf. Kirch et al. 1991:159) concluded that between $88 \%$ and $100 \%$ of the pottery was of non-local origin, with some probably originating from the Manus area. Dickinson (2006:76, Table 25E5-7, Appendix Table A1) extended this to include the Tabar-Lihir-Tanga-Feni Islands off the east coast of New Ireland, with Tanga also contributing to the Anir group to the south. Dickinson (2000:177, 2006: Table 25C2) has further suggested a possible Manus and New Ireland-New Hanover origin for some Watom pottery.

This widespread transport of pottery across the entire Archipelago emphasises the connectedness of Lapita pottery-using communities that is also indicated by the distribution of obsidian from the New Britain and Manus sources (Kirch 1997:242-246; Summerhayes 2001b, 2003, 2004). We do not know whether this connectedness, which lasted for several hundred years, involved only finished pots or the raw materials, with or without the potters themselves (Summerhayes 2001a, 2001c). The high proportion of exotic pottery in the Mussau sites and the importation of all pottery to Nissan raise several questions. For example, what did the inhabitants of the islands receiving the pottery contribute to its development in the formative period? Were only completed pots transferred between the islands, or did potters and their raw materials move together? Can we assume that the transfer of pots or raw materials was between culturally, if not socially related communities? This invites reconsideration of the 'Lapita without pots' scenario (Spriggs 1991:237, 1997:111; cf. Green 1992). Were there production centres that supplied pottery to a local region, and over longer distances to Mussau and Nissan, in return for other commodities, materials or perhaps spouses? We can reasonably assume that if Lapita activity on tiny islands less than 10 hectares in area involved residential use, this must have been sustained by reliance on neighbouring larger landmasses for essential resources of food and materials, either by direct access or through exchange relationships with those resident on the larger landmasses. Were exchange relationships with members of the same or a different ethnolinguistic group? These and other questions have yet to be explored, especially in terms of how we might address them through the archaeological record (Specht and Torrence this volume).

The association of 'special objects and ceramics' with the stilt structure at ECA/B, and the contrast in the finds from this area and those from ECA/A and W250N170 might be repeated at other locations, such as Boduna and the Duke of York Islands. Perhaps the construction of buildings in the inter-tidal zone was an alternative to using tiny offshore islands. The linking of face designs and some vessel forms with deities or ancestors, and the possible use of cylinder stands as sound-producing instruments open opportunities for viewing at least some Lapita spaces as focal points of ceremonial or religious activity that required close association with the sea and comparative isolation from land.

\section{Conclusions}

The complex human history of the Bismarck Archipelago matches its complex geological history. The local environments of many Lapita sites in the Archipelago have undergone substantial post-depositional alteration as a result of natural processes and events, as well as sediment accumulation and disturbance due to human 
activities. Today's landscapes often bear little resemblance to those of the formative period, and there is clearly need for focused environmental histories such as those constructed for the Mussau Islands and the Arawes.

Improved chronologies are also essential for understanding the formative period, and could include re-dating of key locations to take advantage of the greater precision offered by the AMS technique. We need to understand better the internal structure of individual sites as a product of a complex range of human activities, and to disentangle the temporal relationships of sites in the same and different island groups. These are essential steps for testing suggestions about contemporary use of areas for different activities and the possibility of 'satellite' relationships between adjacent sites. Improved chronologies, however, will not be the complete answer. The degree of discrimination we need to address some questions may be beyond the capacity of radiocarbon dating to deliver, particularly if the duration of the formative period is encompassed by the age spans of calibrated results (cf. Kirch 2001b:220). Bayesian analysis of dates may assist, but this must be informed by detailed stratigraphic, stylistic and spatial studies of pottery and other categories of the archaeological record.

This paper has dealt with questions and speculations without resolving specific issues, but hopefully it has raised some potentially useful lines for further examination of the formative period of Lapita cultural complex in the Bismarck Archipelago. Pursuit of these, however, will require us to suspend orthodox views about the history and nature of the complex across its vast distribution, so we can focus on the increasingly complex record in the area of its initial expression. This hopefully will open new perspectives that are more nuanced than current models permit, and perhaps result in 'an unfamiliar Lapita' (Spriggs 2002:55) that also illuminates the wider picture.

\section{Endnotes}

1. I use 'Bismarck Archipelago' in the German-period sense to refer to the islands that today form the Manus, New Ireland and East and West New Britain Provinces of Papua New Guinea. Nissan was part of the 'deutsche Salomo-Inseln' ('the German Solomon Islands'), which I refer to here as the 'north Solomons' in a geographical sense. 'Solomon Islands' refers to the entire Solomon Islands chain without geo-political reference.

2. The potential number of plant-derived samples was more than the 26 included in Table 1 . Samples with standard deviations greater than 115 years are excluded as they yield large calibrated age ranges (600-1360 years at 2 $\sigma$ ) of limited value for defining the chronology of Lapita sites. Most samples selected have age spans of less than 400 years at the HPD; the four samples with standard deviations of 100-115 years have the largest age spans (459-567 years). The text does not take into account the effect of plateaux in the calibration curve around 3500-2500 cal. BP (Blackwell et al. 2006:411).

3. There is, of course, a terminological issue here. The vessel forms and designs and other cultural elements that were transported southwards during the initial dispersal would have been the same as in the Bismarck Archipelago and could therefore logically be seen as part of the 'formative' period. These close similarities applied only to the earliest stage of dispersal; each area subsequently diverged from the ancestral forms and took on distinctive local characteristics.

4. Parsonson (1965:14-15, 1968:571) included relative humidity, temperature and wind speed as factors in deterring mosquito activity, and observed a mosquito '600 yards out to sea,' though '50-60 yards of salt-water is sufficient to throw the mosquito “off the scent."' Groube (1993), Spriggs (1997:39-40, 103-104) and Kirch (1997:110-113, 292 footnote 45) discuss mosquitoes and malaria, including the impact of malaria on life expectancy, levels of immunity and possible genetic advantages in some populations.

5. The term 'village' is used explicitly in the title of the chapter describing research at ECA, ECB and EHB (Kirch 2001a).

6 . The $6 \mathrm{~m}^{3}$ excavated at ECA / A produced about 1500 sherds ( 250 sherds $\left./ \mathrm{m}^{3}\right)$, of which only two were decorated (Kirch 2001a:Table 4.1, 85). In contrast, the $17.6 \mathrm{~m}^{3}$ excavated at ECA/B yielded nearly 24,000 sherds $\left(\sim 1350\right.$ sherds $\left./ \mathrm{m}^{3}\right)$, about $10 \%$ of which were decorated (Kirch 2001a:Table 4.3). Comparable data are not available for ECB. 
7. The base of FEA is dated on marine shells to about 3340-3000 cal. BP, with $\Delta \mathrm{R}=0 \pm 0$ (Specht and Summerhayes in press). Ambrose and Gosden (1991:187) described the pottery recovered in 1985 as 'Western Lapita.' White et al. (2002) extended this to include 'Far Western Lapita.' The weathered nature of the Ambrose-Gosden sherds limits what can be said about them, but they are generally closer to the 1989 excavated sample than to the inter-tidal zone and lagoon floor collections. The expression 'complex forms' used in this paragraph refers to vessels with elaborated rims and/or markedly angular carinated shoulders, bowl-on-stand, pot stand and cylinder stand.

8. FDK is an inter-tidal location at the foot of a $40 \mathrm{~m}$-high ridge running from Mt Kutau. The narrow 'coastal plain' here is primarily the result of landfill in the colonial period to construct a road between Talasea and settlements on the western side of Willaumez Peninsula. In Lapita times FDK was probably a locale over the inter-tidal reef flat.

9. Matthew Spriggs (personal communication) tells me he has discussed with several others the idea of cylinder stands as sound-producing instruments.

10. Garanger (1971:65, Fig. 2) compared the animal figurines of his 'Early Mangaasi' pottery with those on modern Adzera meat-cooking pots, where the animals represent a flying fox, bat, amphibians and birds (May and Tuckson 1982:142143, Figs 6.16, 6.17). Bird figures have also been found on a dentate-stamped vessel at Teouma (Bedford et al. 2006:819), as well as 'human' heads at several other Lapita sites (Torrence and White 2001).

11. The Teouma cemetery provides the only evidence for the use of Lapita vessels as ossuaries. No vessels, complete or otherwise, were associated with the burials at SAC on Watom Island (Green et al. 1989) or at other locations where human remains of the dentate-stamped Lapita period have been recovered. A large bowl with paddle-impressed decoration of the 'Podtanean tradition' covered the skull of a burial at WKO013C (Valentin 2003:285). The 'pottery pit' at WKO013A in New Caledonia did not contain bones, but both main pots had part of their bases removed prior to insertion into the pits (Sand et al. 1998:37). Bedford (2006) has described a dentate-stamped pot from Vao in Vanuatu where the design was deliberately obscured by a white pigment. Perhaps the WKO013A and Vao vessels also played a role in mortuary or related rites?

\section{References}

Allen, J. 1984. In search of the Lapita homeland: reconstructing the prehistory of the Bismarck Archipelago. Journal of Pacific History 19(4): 186-201.

Ambrose, W.R. and C. Gosden 1991. Investigations on Boduna Island. In J. Allen and C. Gosden (eds), Report of the Lapita Homeland Project, pp.182-188. Canberra: Department of Prehistory, Australian National University. Occasional Papers in Prehistory 20.

Anderson, A., G. Clark and T. Worthy 2000. An inland Lapita site in Fiji. Journal of the Polynesian Society 109: 311-316.

Anderson, A., S. Bedford, G. Clark, I. Lilley, C. Sand, G. Summerhayes and R. Torrence 2001. An inventory of Lapita sites containing dentate-stamped pottery. In G.R. Clark, A.J. Anderson and T. Vunidilo (eds), The Archaeology of Lapita Dispersal in Oceania, pp. 1-13. Canberra: Pandanus Books, Research School of Pacific and Asian Studies, Australian National University. Terra Australis 17.

Anson, D. 1986. Lapita pottery of the Bismarck Archipelago and its affinities. Archaeology in Oceania 21(3): 157-165.

Anson, D, R. Walter and R.C. Green 2005. A Revised and Redated Event Phase Sequence for the Reber-Rakival Lapita Site, Watom Island, East New Britain Province, Papua New Guinea. Dunedin: Department of Anthropology, University of Otago. University of Otago Studies in Prehistoric Archaeology 20.

Bedford, S. 2006. The Pacific's earliest painted pottery: an added layer of intrigue to the Lapita debate and beyond. Antiquity 80: 544-557.

Bedford, S., M. Spriggs and R. Regenvanu 2006. The Teouma Lapita site and the early settlement of the Pacific Islands. Antiquity 80: 812-828.

Bellwood, P. 1978. Man's Conquest of the Pacific. The prehistory of Southeast Asia and Oceania. Auckland: Collins. 
Bellwood, P. 1992. New discoveries in Southeast Asia relevant for Melanesian (especially Lapita) prehistory. In J-C. Galipaud (ed.), Poterie Lapita et Peuplement, pp. 49-66. Nouméa: ORSTOM.

Blackwell, R.R., C.E. Buck and P.J. Reimer 2006. Important features of the new radiocarbon calibration curves. Quaternary Science Reviews 25: 408-413.

Best, S. 2002. Lapita: A view from the East. Auckland: New Zealand Archaeological Association. Monograph 24.

Boyd, W.E., C.J. Lentfer and J. Parr 2005. Interactions between human activity, volcanic eruptions and vegetation during the Holocene at Garua and Numundo, West New Britain. Quaternary Research 64: 384-398.

Chiu, S. 2003. The Socio-economic Functions of Lapita Ceramic Production and Exchange: A Case Study from Site WKO013 A, Koné, New Caledonia. Unpublished PhD thesis, University of California, Berkeley.

Chiu, S. 2005. Meanings of a Lapita face: materialized social memory in ancient house societies. Taiwan Journal of Anthropology 3(1): 1-47.

Chowning, A. 1968. The real Melanesia: a critique of Parsonson's theories. Mankind 6(12): 641-652.

Crowther, A. 2005. Starch residues on undecorated Lapita pottery from Anir, New Ireland. Archaeology in Oceania 40(2): $62-66$.

Dickinson, W.R. 2000. Petrography of sand tempers in prehistoric Watom sherds and comparison with temper suites of the Bismarck Archipelago. New Zealand Journal of Archaeology 20 (1998): 161-182.

Dickinson, W.R. 2006. Temper Sands in Prehistoric Oceanian Pottery: Geotectonics, Sedimentology, Petrography, Provenance. Boulder: The Geological Society of America. Special Paper 406.

Felgate, M.W. 2003. Reading Lapita in Near Oceania: Intertidal and Shallow Water Pottery Scatters, Roviana Lagoon, New Georgia, Solomon Islands. Unpublished PhD thesis, University of Auckland, Auckland.

Fischer, H. 1983. Sound-producing Instruments in Oceania. Translated by P.W. Holzknecht and edited by D. Niles. Boroko (PNG): Institute of Papua New Guinea Studies.

Frimigacci, D. 1980. Localisation éco-géographique et utilisation de l'espace de quelques sites Lapita de NouvelleCalédonie. Journal de la Société des Océanistes 66-67 (36): 5-11.

Galipaud, J-C. 2000. The Lapita site at Atanoasao, Malo, Vanuatu. World Archaeological Bulletin 12: 41-55.

Garanger, J. 1971. Incised and applied-relief pottery, its chronology and development in Southeastern Melanesia, and extra-areal comparisons. In R.C. Green and M. Kelly (eds), Studies in Oceanic Culture History vol. 2, pp. 53-66. Honolulu: B.P. Bishop Museum. Pacific Anthropological Records 12.

Gosden, C. 1989. Prehistoric social landscapes of the Arawe Islands, West New Britain Province, Papua New Guinea. Archaeology in Oceania 24(2): 45-58.

Gosden, C. and J. Webb 1994. The creation of a Papua New Guinean landscape: archaeological and geomorphological evidence. Journal of Field Archaeology 21(1): 29-51.

Gosden, C., J. Webb, B. Marshall and G.R. Summerhayes 1994. Lolmo Cave: a mid- to late Holocene site, the Arawe Islands, West New Britain Province, Papua New Guinea. Asian Perspectives 33(1): 97-119.

Green, R.C. 1976. Lapita sites in the Santa Cruz group. In R.C. Green and M.M. Creswell (eds), Southeast Solomon Islands Cultural History, pp. 245-265. Wellington: Royal Society of New Zealand. Bulletin 11.

Green, R.C. 1979. Lapita. In J.D. Jennings (ed.), The Prehistory of Polynesia, pp. 27-60. Cambridge (Mass.): Harvard University Press.

Green, R.C. 1991a. A reappraisal of the dating of some Lapita sites in the Reef/Santa Cruz Group of the southeast Solomons. Journal of the Polynesian Society 100(2): 197-207.

Green, R.C. 1991b. The Lapita Cultural Complex: current evidence and proposed models. Indo-Pacific Prehistory Association Bulletin 11: 295-305.

Green, R.C. 1992. Definitions of the Lapita Cultural Complex and its non-ceramic component. In J-C. Galipaud (ed.), Poterie Lapita et Peuplement, pp. 7-20. Nouméa: ORSTOM. 
Green, R.C. 2000. Lapita and the cultural models for intrusion, integration and innovation. In A. Anderson and T. Murray (eds), Australian Archaeologist: collected papers in honour of Jim Allen, pp. 372-392. Canberra: Coombs Academic Publishing, Australian National University.

Green, R.C. 2003. The Lapita horizon and traditions - signature for one set of Oceanic migrations. In C. Sand (ed.), Pacific Archaeology: Assessments and prospects, pp. 95-120. Nouméa: Département d'Archéologie, Service des Musées et du Patrimoine de Nouvelle-Calédonie. Les Cahiers de l'Archéologie en Nouvelle-Calédonie 15.

Green, R.C. and D. Anson 2000. Excavations at Kainapirina (SAC), Watom Island, Papua New Guinea. New Zealand Journal of Archaeology 20 (1998): 29-94.

Green, R.C., D. Anson and J. Specht 1989. The SAC burial ground, Watom Island, Papua New Guinea. Records of the Australian Museum 41(3): 215-221.

Green, R.C. and A. Pawley 1998. Architectural forms and settlement patterns. In M. Ross, A. Pawley and M. Osmond (eds), The Lexicon of Proto Oceanic: The culture and environment of ancestral Oceanic society. Vol. 1. Material culture, pp. 37-65. Canberra: Pacific Linguistics. Pacific Linguistics C152.

Groube, L.M. 1971. Tonga, Lapita pottery and Polynesian origins. Journal of the Polynesian Society 86: 7-36.

Groube, L.M. 1993. Contradictions and malaria in Melanesian and Australian prehistory. In M. Spriggs, D.E. Yen, W. Ambrose, R. Jones, A. Thorne and A. Andrews (eds), A Community of Culture: The people and prehistory of the Pacific, pp. 164-186. Canberra: Department of Prehistory, Research School of Pacific Studies, Australian National University. Occasional Papers in Prehistory 21.

Groves, W.C. 1934. The natives of Sio Island, south-eastern New Guinea: a study in culture contact. Oceania 5(1): 43-63.

Holzknecht, K. 1957. Über Töpferei und Tontrommeln der Azera in Ost-Neuguinea. Zeitschrift für Ethnologie 82: 97-111.

Horrocks, M. and S. Bedford 2005. Microfossil analysis of Lapita deposits in Vanuatu reveals introduced Araceae (aroids). Archaeology in Oceania 40(2): 67-74.

Hunt, T.L. 1989. Lapita Ceramic Exchange in the Mussau Islands, Papua New Guinea. Unpublished PhD thesis, University of Washington, Seattle.

Irwin, G. 1981. How Lapita lost its pots: the question of continuity in the colonisation of Polynesia. Journal of the Polynesian Society 90(4): 481-494.

Ivens, W.G. 1930. The Island Builders of the Pacific. London: Seeley, Service and Co.

Kirch, P.V. 1988a. The Talepakemalai Lapita site and Oceanic prehistory. National Geographic Research 4(3): 328-342.

Kirch, P.V. 1988b. Long-distance exchange and island colonisation: the Lapita case. Norwegian Archaeological Review 21(2): 103-117.

Kirch, P.V. 1996. Lapita and its aftermath: the Austronesian settlement of Oceania. In W.H. Goodenough (ed.), Prehistoric Settlement of the Pacific, pp. 57-70. Philadelphia: American Philosophical Society. Transactions of the American Philosophical Society 86(5).

Kirch, P.V. 1997. The Lapita Peoples: Ancestors of the Oceanic world. Oxford: Blackwell.

Kirch, P.V. 2000. On the Road of the Winds: An archaeological history of the Pacific Islands before European contact. Berkeley: University of California Press.

Kirch, P.V. 2001a. Three Lapita villages: excavations at Talepakemalai (ECA), Etakosarai (ECB), and Etapakengaroasa (EHB), Eloaua and Emananus Islands. In P.V. Kirch (ed.), Lapita and its Transformations in Near Oceania, pp. 68-145. Berkeley: Archaeological Research Facility, University of California at Berkeley. Contribution 59.

Kirch, P.V. 2001b. A radiocarbon chronology for the Mussau Islands. In P.V. Kirch (ed.), Lapita and its Transformations in Near Oceania, pp. 196-222. Berkeley: Archaeological Research Facility, University of California at Berkeley. Contribution 59 . 
Kirch, P.V. and T.L. Hunt. 1988a. The spatial and temporal boundaries of Lapita. In P.V. Kirch and T.L. Hunt (eds), Archaeology of the Lapita Cultural Complex: A critical review, pp. 9-31. Seattle: Thomas Burke Memorial Washington State Museum. Report 5.

Kirch, P.V. and T.L. Hunt 1988b. Radiocarbon dates from the Mussau Islands and the Lapita colonization of the Southwest Pacific. Radiocarbon 30(2):161-169.

Kirch, P.V., T.L. Hunt, M. Weisler, V. Butler, and M.S. Allen 1991. Mussau Islands prehistory: results of the 1985-86 excavations. In J. Allen and C. Gosden (eds), Report of the Lapita Homeland Project, pp. 144-163. Canberra: Department of Prehistory, Research School of Pacific Studies, Australian National University. Occasional Papers in Prehistory 20.

Kumar, R. 2002. Discovery of a Lapita sherd inland of the Northeast coast of Viti Levu Island, Fiji: insights and implications. IAS Technical Report 2002/5. Suva: Institute of Applied Sciences, University of the South Pacific.

Kumar, R. and P.D. Nunn 2003. Inland and coastal Lapita settlement on Vitilevu Island, Fiji: new data. Domodomo 16(1): 15-20.

Kunst, J. 1967. Music in New Guinea. Three studies. Verhandelingen van het Koninklijk Instituut voor Taal-, Land- en Volkenkunde 53.

Lauer, P.K. 1970. Sailing with the Amphlett Islanders. Journal of the Polynesian Society 79(4): 381-398.

Lauer, P.K. 1973. The technology of pottery manufacture on Goodenough Island and in the Amphlett Group, S.E. Papua. Ocasional Papers of the Anthropology Museum, University of Queensland 2: 25-60.

Lepofsky, D. 1988. The environmental context of Lapita settlement locations. In P.V. Kirch and T.L. Hunt (eds), Archaeology of the Lapita Cultural Complex: A critical review, pp. 33-47. Seattle: Thomas Burke Memorial Washington State Museum Report 5.

May, P. and M. Tuckson 1982. The Traditional Pottery of Papua New Guinea. Sydney: Bay Books.

McClean, M. 1994. Diffusion of Musical Instruments and their Relationship to Language Migrations in New Guinea. Port Moresby: National Research Institute. Kulele: Occasional Papers in Pacific Music and Dance 1.

Noury, A. 2005. Le Reflet de l'Âme Lapita. Versailles: A. Noury, privately published.

Nunn, P.D., R. Kumar, S. Matararaba, T. Ishimura, J. Seeto, S. Rayawa, S. Kuruyawa, A. Nasila, B. Oloni, A.R. Ram, P. Saunivalu, P. Singh and E. Tegu 2004. Early Lapita settlement at Bourewa, southwest Viti Levu Island, Fiji. Archaeology in Oceania 39(3): 139-148.

Parsonson, G.S. 1965. Artificial islands in Melanesia: the role of malaria in the settlement of the Southwest Pacific. New Zealand Geographer 22(1): 1-21.

Parsonson, G.S. 1968. The problem of Melanesia. Mankind 6(11): 571-584.

Petrie, C., and R. Torrence in prep. The chronology of eruption, abandonment and reoccupation, West New Britain c.7500 BC - AD 1880.

Petchey, F., M. Phelan and P. White 2004. New $\Delta$ R values for the southwest Pacific Ocean. Radiocarbon 46(2): 1005-1014.

Petchey, F., R.C. Green, M. Jones and M. Phelan 2005. A local marine reservoir correction value $(\Delta R)$ for Watom Island, Papua New Guinea. New Zealand Journal of Archaeology 26(2004): 29-40.

Pineda, R. and J-C. Galipaud 1998. Evidences archéologiques d'une surrection différentielle de l'île Malo (archipel du Vanuatu) au cours de l'Holocène recent. Comptes-rendus de l'Académie des Sciences de Paris. Sciences de la Terre et des Planètes 327: 777-779.

Pisarik, S. 1975. Micronesian Atoll Populations: A Path Analysis. Unpublished MA thesis, University of Iowa, Iowa City.

Reimer, P.J., M.G.L. Baillie, E. Bard, A. Bayliss, J.W. Beek, C.J.H. Bertrand, R.G. Blackwell, C.E. Buck, G.S. Burr, K.B. Cutler, P.E. Damon, R.L. Edwards, R.G. Fairbanks, M. Friedrich, T.P. Guilderson, A.G. Hogg, K.A. Hughen, B. Kromer, F.G. McCormac, S.W. Manning, C.B. Ramsey, R.W. Reimer, S. Remmele, J.R. Southon, M. Stuiver, S. Talamo, F.W. Taylor, J. van der Plicht and C.E. Weyhenmeyer 2004. IntCal04 terrestrial radiocarbon age calibration, 26-0 ka BP. Radiocarbon 46: 1029-1058. 
Sand, C., K. Coote, J. Bolé and A. Ouetcho 1998. A pottery pit at locality WKO013A, Lapita (New Caledonia). Archaeology in Oceania 33(1): 37-43.

Sheppard, P.J. and R.C. Green 1991. Spatial analysis of the Nenumbo (SE-RF-2) Lapita site, Solomon Islands. Archaeology in Oceania 26(3): 89-101.

Specht, J. 1974. Lapita pottery at Talasea, West New Britain, Papua New Guinea. Antiquity 48: 302-306.

Specht, J. 1991. Kreslo: a Lapita site in southwest New Britain, Papua New Guinea. In J. Allen and C. Gosden (eds), Report of the Lapita Homeland Project, pp. 189-204. Canberra: Department of Prehistory, Research School of Pacific Studies, Australian National University. Occasional Papers in Prehistory 20.

Specht, J. in press. The Lagenda Lapita site (FCR/FCS), Talasea area, Papua New Guinea. Technical Reports of the Australian Museum.

Specht, J. and C. Gosden 1997. Dating Lapita pottery in the Bismarck Archipelago. Asian Perspectives 36(2): 175-199.

Specht, J. and G. Summerhayes in press. The Boduna Island (FEA) Lapita site, Papua New Guinea. Technical Reports of the Australian Museum.

Specht, J. and R. Torrence in press. Pottery sites of the Talasea area, Papua New Guinea. Technical Reports of the Australian Museum.

Spriggs, M. 1984. The Lapita cultural complex: origins, distribution, contemporaries and successors. Journal of Pacific History 19(4): 202-223.

Spriggs, M. 1990. The changing face of Lapita: transformations of a design. In M. Spriggs (ed.), Lapita Design, Form and Composition, pp. 83-122. Canberra: Department of Prehistory, Research School of Pacific Studies, Australian National University. Occasional Papers in Prehistory 19

Spriggs, M. 1991. Nissan: The island in the middle. In J. Allen and C. Gosden (eds), Report of the Lapita Homeland Project, pp. 222-243. Canberra: Department of Prehistory, Research School of Pacific Studies, Australian National University. Occasional Papers in Prehistory 20.

Spriggs, M. 1995. The Lapita culture and Austronesian prehistory in Oceania. In P. Bellwood, J.J. Fox and D. Tryon (eds), The Austronesians: Historical and Comparative Perspectives, pp. 112-133. Canberra: Department of Anthropology, Research School of Pacific and Asian Studies, Australian National University.

Spriggs, M. 1996. What is Southeast Asian about Lapita? In T. Azakawa and E. Szathmary (eds), Prehistoric Mongoloid Dispersals, pp. 324-348. Oxford: Oxford University Press.

Spriggs, M. 1997. The Island Melanesians. Oxford: Blackwell.

Spriggs, M. 2000. The Solomon Islands as bridge and barrier in the settlement of the Pacific. In A. Anderson and T. Murray (eds), Australian Archaeologist: Collected Papers in Honour of Jim Allen, pp. 348-364. Canberra: Coombs Academic Publishing, Australian National University.

Spriggs, M. 2002. They've grown accustomed to your face. In S. Bedford, C. Sand and D. Burley (eds), Fifty Years in the Field. Essays in honour and celebration of Richard Shutler Jr's archaeological career, pp. 51-57. Auckland: New Zealand Archaeological Association Monograph 25.

Spriggs, M. 2003a. Post-Lapita evolutions in Melanesia. In C. Sand (ed.), Pacific Archaeology: Assessments and prospects, pp. 205-212. Noumea: Département d'Archéologie, Service des Musées et du Patrimoine de NouvelleCalédonie. Les Cahiers de l'Archéologie en Nouvelle-Calédonie 15.

Spriggs, M. 2003b. Chronology of the Neolithic transition in Island Southeast Asia and the Western Pacific: a view from 2003. The Review of Archaeology 24(2): 57-80.

Steadman, D.W. 2006. Extinction and Biogeography of Tropical Pacific Birds. Chicago: University of Chicago Press.

Steadman, D.W. and P.V. Kirch 1998. Biogeography and prehistoric exploitation of birds in the Mussau Islands, Bismarck Archipelago, Papua New Guinea. Еmu 98: 13-22.

Stuiver, M. and P.J. Reimer 1993. Extended 14C database and revised CALIB radiocarbon calibration program. Radiocarbon 35: 215-30. 
Summerhayes, G. 2000a. What's in a pot? In A. Anderson and T. Murray (eds), Australian Archaeologist. Collected papers in honour of Jim Allen, pp. 291-307. Canberra: Coombs Academic Publishing, Australian National University.

Summerhayes, G. 2000b. Lapita Interaction. Canberra: Department of Archaeology and Natural History, and Centre for Archaeology, Australian National University. Terra Australis 15.

Summerhayes, G.R. 2001a. Defining the chronology of Lapita in the Bismarck Archipelago. In G.R. Clark, A.J. Anderson and T. Vunidilo (eds), The Archaeology of Lapita Dispersal in Oceania, pp. 25-38. Canberra: Pandanus Books, Research School of Pacific and Asian Studies, Australian National University. Terra Australis 17.

Summerhayes, G.R. 2001b. Far Western, Western, and Eastern Lapita: a re-evaluation. Asian Perspectives 39(1-2): 109-118.

Summerhayes, G.R. 2001c. Lapita in the Far West: recent developments. Archaeology in Oceania 36(2): 53-64.

Summerhayes, G.R. 2003. Modelling differences between Lapita obsidian and pottery distribution patterns in the Bismarck Archipelago, Papua New Guinea. In C. Sand (ed.), Pacific Archaeology: Assessments and prospects, pp. 135-145. Noumea: Département d'Archéologie, Service des Musées et du Patrimoine de NouvelleCalédonie. Les Cahiers de l'Archéologie en Nouvelle-Calédonie 15.

Summerhayes, G. 2004. The nature of prehistoric obsidian importation to Anir and the development of a 3,000 year old regional picture of obsidian exchange within the Bismarck Archipelago, Papua New Guinea. Records of the Australian Museum, Supplement 29: 145-156.

Summerhayes, G.R. in press. The rise and transformation of Lapita in the Bismarck Archipelago. In S. Chiu and C. Sand (eds), From Southeast Asia to the Pacific: Archaeological perspectives on the Austronesian expansion and the Lapita Cultural Complex. Taipei: Center for Archaeological Studies Research and Center for Humanities and Social Sciences, Academia Sinica.

Terrell, J.E. 1998. 30,000 years of culture contact in the southwest Pacific. In J.G. Cusick (ed.), Studies in Culture Contact: Interaction, culture change, and archaeology, pp. 191-219. Carbondale: Centre for Archaeological Investigations, Southern Illinois University. Occasional Paper 25.

Terrell, J.E. 2004. Introduction: 'Austronesia' and the great Austronesian migration. World Archaeology 36(4): 586-590.

Terrell, J.E. and R.L. Welsch 1997. Lapita and the temporal geography of prehistory. Antiquity 71: 548-572.

Thomson, J-A.R. and J.P. White 2000. Localism of Lapita pottery in the Bismarck Archipelago. In A. Anderson and T. Murray (eds), Australian Archaeologist: Collected papers in honour of Jim Allen, pp.308-323. Canberra: Coombs Academic Publishing, Australian National University.

Torrence, R. and C.M. Stevenson 2000. Beyond the beach: changing Lapita landscapes on Garua Island, Papua New Guinea. In A. Anderson and T. Murray (eds), Australian Archaeologist: Collected Papers in Honour of Jim Allen, pp. 324-345. Canberra: Coombs Academic Publishing, Australian National University.

Torrence, R. and J.P. White 2001. Tattooed faces from Boduna Island, Papua New Guinea. In G.R. Clark, A.J. Anderson and T. Vunidilo (eds), The Archaeology of Lapita Dispersal in Oceania, pp. 135-140. Canberra: Pandanus Books, Australian National University. Terra Australis 17.

Valentin, F. 2003. Human skeletal remains from the site of Lapita at Koné (New Caledonia): Mortuary and biological factors. In C. Sand (ed.), Pacific Archaeology: Assessments and prospects, pp. 285-293. Noumea: Départment Archéologie, Service des Musées et du Patrimoine de Nouvelle-Calédonie. Les Cahiers de l'Archéologie en Nouvelle-Calédonie 15.

Weisler, M. 2001a. Life on the edge: prehistoric settlement and economy on Utrok Atoll, northern Marshall Islands. Archaeology in Oceania 36: 109-133.

Weisler, M. 2001b. On the Margins of Sustainability: Prehistoric Settlement of Utrok Atoll, Northern Marshall Islands. Oxford: Archaeopress. British Archaeological Reports, International Series 967.

White, J.P. in press. Ceramic sites on the Duke of York Islands. Technical Reports of the Australian Museum. 
White, J.P., C. Coroneos, V. Neall, W. Boyd and R. Torrence 2002. FEA site, Boduna Island: further investigations. In S. Bedford, C. Sand and D. Burley (eds), Fifty Years in the Field. Essays in honour and celebration of Richard Shutler Jr's archaeological career, pp. 101-107. Auckland: New Zealand Archaeological Association. Monograph 25.

White, J.P. and M-N. Harris 1997. Changing sources: early Lapita period obsidian in the Bismarck Archipelago. Archaeology in Oceania 32(1): 97-107.

Wickler, S. 2001. The Prehistory of Buka: A stepping stone island in the Northern Solomons. Canberra: Department of Archaeology and Natural History, and Centre for Archaeological Research, Australian National University. Terra Australis 16. 